\title{
Astrological Biochemistry of Vitamins
}

\section{Mayank Dimri, Luv Kush}

SBS University Balawala, Dehradun-Utttarakhand, India

\section{A B S T R A C T}

Vitamins are organic compounds and an integral part of the balanced diet. Biochemically they function as coenzymes. The vitamins belong to the zodiacal sign Virgo in astrological parlance. They complement medicine by the application of astrological knowledge for the eradication of aliments.

Keywords: Vitamins, Astrology, Deficiency, Coenzyme, Balance diet, Aliments.

\section{A R T I C L E I N F 0: Received 21 Oct.2019; $\quad$ Review Completed 07 Dec.2019; $\quad$ Accepted 08 Feb 2020; \\ Available online 15 Feb. 2020 \\ Cite this article as: \\ Mayank Dimri, Luv Kush, Astrological Biochemistry of Vitamins, Asian Journal of Pharmaceutical Research and Development. 2020; 8(1):82-85. DOI: http://dx.doi.org/10.22270/ajprd.v8i1.635}

\section{*Address for Correspondence:}

\section{INTRODUCTION}

$\mathrm{V}$ itamins are organic compounds ${ }^{1-2}$ and integral part of the balance diet. They are required in small amounts and perform specific cellular function, therefore essential for the normal metabolism. Biochemically they function as coenzymes. The certain vitamins have chemo preventive roles in the cardiovascular disorders (Niacin), cancer (Vitamin C), and infections (Vitamin A).

The assimilative solubility in intestine classified vitamins into lipid and water soluble.

- Lipid soluble vitamins: Vitamins A, D, E and K.

- Water soluble vitamins: They are sub classified into non-B-complex (Vitamin c) and vitamin B-complex, which is further classified in three categories:

- Energy releasing (Vitamin B1 Thiamine, Vitamin B2 Riboflavin, Vitamin B3 Niacin, Biotin)

- Hematopoietic (Folic acid, Vitamin B12)

- Miscellaneous (Vitamin B6)

Astrologically vitamins belongs to Zodiac sign Virgo ${ }^{3-4}$. It is related to Spica constellation, depicted holding a spike(composed of many grains and vitamins containing foods).

Their benefic effects bring prosperous health and freedom from disease. Vitamins become important in following conditions.

- Great physical exertion
- Active sports

- In old age

- The irregular energy supply

- When dieting for weight loss

- During lactation and pregnancy

- In season with lack of fresh vegetables

The cosmopolitan sources of vitamins are fruits, vegetables, nuts, eggs, dairy products, mushrooms, oils and seeds.

\section{Theoretical Methodology}

Mercury planet rules Gemini and Virgo signs. They command the affairs of $3^{\text {rd }}$ and $6^{\text {th }}$ houses respectively. Gemini conveys biological information and knowledge for cellular communication in cell sociology. Virgo governs absorption, assimilation and biosynthesis of vitamins in microbial flora of intestines.

The intestinal hygiene is essential for the absorption of vitamins especially in Earth signs (Taurus, Virgo, Capricorn). The antibiotics and other drugs block the absorption of vitamins.

The degrees of Virgo and Gemini determine, diet, nutrition and digestibility. They can help to identify area of Zodiacal weakness (detrimental and opposite signs of planets and signs).The natal position of Sun in the signs show possible chronic deficiency of vitamins. Sagittarius and Pisces are the most disadvantaged in this respect.

A comprehensive review of medically oriented knowledge $^{5-9}$ is briefed in tables one and two. 
Table 1: Astro-medical Profiles of Zodiacal Signs

\begin{tabular}{|c|c|c|c|}
\hline $\begin{array}{l}\text { Zodiacal signs and their } \\
\text { rulers }\end{array}$ & Human body organs ruled & Aliments & Tissue salts \\
\hline $\begin{array}{l}\text { Aries } \\
\text { Mars }\end{array}$ & $\begin{array}{l}\text { Head, brain, eyes, face, muscles } \\
\text { and pineal gland }\end{array}$ & $\begin{array}{l}\text { Headache, migraine, sinus problems, high BP, skin } \\
\text { eruptions, burns, faintness, fever, inflammation, } \\
\text { neuralgia, insect bites and stings }\end{array}$ & $\begin{array}{l}\text { Potassium phosphate helps } \\
\text { nerves and brain imbalances. }\end{array}$ \\
\hline $\begin{array}{l}\text { Taurus } \\
\text { Venus }\end{array}$ & $\begin{array}{l}\text { Neck, throat, thyroid gland, } \\
\text { larynx, chin, lower jaw, ears, } \\
\text { tongue, vocal chords }\end{array}$ & $\begin{array}{l}\text { Stiff neck, tension, excess weight obesity, apoplexy, sore } \\
\text { throat, diphtheria, tonsillitis and hypothyroidism }\end{array}$ & $\begin{array}{l}\text { Sodium sulphate regulates } \\
\text { metabolism and water supply. }\end{array}$ \\
\hline $\begin{array}{l}\text { Gemini } \\
\text { Mercury }\end{array}$ & $\begin{array}{l}\text { Hands, fingers, arms, shoulders, } \\
\text { nerves system, upper ribs, } \\
\text { lungs, bronchial tracts, trachea } \\
\text { thymus gland }\end{array}$ & $\begin{array}{l}\text { Mental faculty, nerves, nerves strain, lung cancer, } \\
\text { asthma, pleurisy, insomnia, restlessness of mind, chest } \\
\text { and lungs complains, amnesia, pneumonia and } \\
\text { pulmonary disease }\end{array}$ & $\begin{array}{l}\text { Potassium chloride formation } \\
\text { and distribution of fibrin fibrous } \\
\text { growth clogging of nose and } \\
\text { throat. }\end{array}$ \\
\hline $\begin{array}{l}\text { Cancer } \\
\text { Moon }\end{array}$ & $\begin{array}{l}\text { Breast, stomach, lower ribs, } \\
\text { womb and pancreas }\end{array}$ & $\begin{array}{l}\text { Stomach, digestive component, dyspepsia, dropsy, upset } \\
\text { stomach, breast disorders, glaucoma, cataracts, jaundice } \\
\text { and obesity, gastric disorder and lymphatic system }\end{array}$ & $\begin{array}{l}\text { Calcium fluoride good for } \\
\text { muscles and ligament tonicity, } \\
\text { so prevent muscle prolepsis, } \\
\text { healthy teeth enamel. }\end{array}$ \\
\hline $\begin{array}{l}\text { Leo } \\
\text { Sun }\end{array}$ & $\begin{array}{l}\text { Upper back, spine, spleen, } \\
\text { heart, aorta and circulation }\end{array}$ & $\begin{array}{l}\text { Cardiovascular heart problems, hardening of arteries, } \\
\text { back problems, faintness, fever, blood disorder, } \\
\text { aneurysm, high and low BP, angina pectoris spinal, chord } \\
\text { problems }\end{array}$ & $\begin{array}{l}\text { Magnesium phosphate healthy } \\
\text { nerve tissue } \\
\text { neurotransmission }\end{array}$ \\
\hline $\begin{array}{l}\text { Virgo } \\
\text { Mercury }\end{array}$ & $\begin{array}{l}\text { Nerves systems, intestines, } \\
\text { spleen, stomach, nerves, blood, } \\
\text { nails, abdomen, lower dorsal } \\
\text { nerves }\end{array}$ & $\begin{array}{l}\text { Anxiety, nerves tension, intestinal cancer, appendicitis, } \\
\text { cholera, peritonitis, tapeworm, abdominal disorders, } \\
\text { bowel disorder, colic pain and dysentery }\end{array}$ & $\begin{array}{l}\text { Potassium sulphate circulation } \\
\text { of lipids, helps digestion, } \\
\text { kidney function, excretion of } \\
\text { toxins }\end{array}$ \\
\hline $\begin{array}{l}\text { Libra } \\
\text { Venus }\end{array}$ & $\begin{array}{l}\text { Lower back (lumber region), } \\
\text { lumber nerves, blood vessels, } \\
\text { skin, pancreas, adrenal glands, } \\
\text { buttocks and kidneys }\end{array}$ & $\begin{array}{l}\text { Kidneys, abscess, bladder disorder, thigh's disease, } \\
\text { eczema, gout, sexual problems, diabetes, gout and tumors }\end{array}$ & $\begin{array}{l}\text { Sodium phosphate balance the } \\
\text { acid alkaline function, helps } \\
\text { acid function affecting nerves } \\
\text { system }\end{array}$ \\
\hline $\begin{array}{l}\text { Scorpio } \\
\text { Pluto and Mars }\end{array}$ & $\begin{array}{l}\text { Genitals, bladder, cervix, anus, } \\
\text { genital urinary tract and } \\
\text { prostate gland }\end{array}$ & $\begin{array}{l}\text { Prostate cancer, reproductive and excretory system, } \\
\text { venereal diseases, all sexual transmitted problems, and } \\
\text { hemorrhoids, piles, renal stones, ruptures, menstrual } \\
\text { problems }\end{array}$ & $\begin{array}{l}\text { Calcium sulphate building and } \\
\text { sustaining epithelial tissue }\end{array}$ \\
\hline $\begin{array}{l}\text { Sagittarius } \\
\text { Jupiter }\end{array}$ & $\begin{array}{l}\begin{array}{l}\text { Liver, hips, thigh, arterial } \\
\text { system, pelvis }\end{array} \\
\text { femur(thighbone) }\end{array}$ & $\begin{array}{l}\text { Liver and many components of it. As Jupiter's main } \\
\text { keyword is that of expansion, swelling, tumor growth, } \\
\text { over weight, overindulgence in food, alcohol and drugs, } \\
\text { Rheumatoid }\end{array}$ & $\begin{array}{l}\text { Silica building and maintaining } \\
\text { skin, hair, nails, and nerve } \\
\text { covers removerr skin } \\
\text { decomposed matter. }\end{array}$ \\
\hline $\begin{array}{l}\text { Capricorn } \\
\text { Saturn }\end{array}$ & $\begin{array}{l}\text { Bones, joints, knees, skin and } \\
\text { teeth }\end{array}$ & $\begin{array}{l}\text { Skin bones disorders degenerative blockages poor } \\
\text { growth, teeth problems, epilepsy, leprosy, constipation, } \\
\text { arthritis and depression }\end{array}$ & $\begin{array}{l}\text { Calcium phosphate bone } \\
\text { builder prevent bone disorders }\end{array}$ \\
\hline $\begin{array}{l}\text { Aquarius } \\
\text { Uranus }\end{array}$ & $\begin{array}{l}\text { Circulatory system, ankles, } \\
\text { Achilles heel, calves, shins and } \\
\text { breath }\end{array}$ & $\begin{array}{l}\text { Stress anxiety, muscular spasms, electric shock, } \\
\text { circulatory problems, arthritis, varicose veins. }\end{array}$ & $\begin{array}{l}\text { Sodium chloride regulate water } \\
\text { regulator of temperature }\end{array}$ \\
\hline $\begin{array}{l}\text { Pisces } \\
\text { Neptune }\end{array}$ & Feet & $\begin{array}{l}\text { Glandular problems, addiction to alcohol, drugs, wasting } \\
\text { diseases, lethargy gradual, erosion of functions, immune } \\
\text { system problem, fluid retention, hormonal imbalances }\end{array}$ & $\begin{array}{lrr}\text { Ferrous } & \text { sulphate } & \text { oxygen } \\
\text { transport } & \text { helps } & \text { blood } \\
\text { circulation } & \text { purity of } & \text { internal } \\
\text { organs. } & & \end{array}$ \\
\hline
\end{tabular}

Table 2: Relationship between Planets and Organs of Human body and Astro-assignment ${ }^{4,7}$ of Vitamins

\begin{tabular}{|l|l|l|}
\hline Planets & Human body parts & Astro-assignment of Vitamins \\
\hline Sun & Cardiovascular spine & Vitamin A \\
\hline Moon & Digestive system & Vitamin B \\
\hline Mars & Muscles, Adrenal glands, Head and Sense of smell and taste & Vitamin K \\
\hline Mercury & Brain, Central nervous system, Thyroid, Hands, and five sense & Vitamin C Thiamine \\
\hline Jupiter & Liver, Thigh ,Feet, Pituitary gland & Vitamin P Flavonoids \\
\hline Venus & Throat, kidneys, Thymus gland, Sense of touch \&Ovaries & Vitamin E \\
\hline Saturn & Skin, Hair, Teeth, Bones, Spleen Immune system & Vitamin D \\
\hline Uranus & Parathyroid gland, Aura neural activity & Vitamin A and U Methionine \\
\hline Neptune & Pineal gland, Psychic healing & Vitamin C \\
\hline Pluto & Pancreas metabolism Elimination & Vitamin B and E \\
\hline
\end{tabular}




\section{Discussion and Results}

Medically human organs are governed by planets and Zodiacal signs, therefore occultly control the physiological chemistry of cells and tissues.

They modulate Zodiacal homeostasis through cosmic energy by keeping all the activities (physical, emotional, intellectual and spiritual) in balanced equilibriums. Whenever they are imbalanced or disturbed by unfavorable planetary aspects and opposite signs (180 degrees) from each other and Detrimental signs for planets:

\begin{tabular}{|l|l|l|l|}
\hline Aries & Libra & Sun (Libra) & Moon (Scorpio) \\
\hline Taurus & Scorpio & Mercury (Pisces) & Mars (Cancer) \\
\hline Gemini & Sagittarius & Venus (Virgo) & Jupiter (Capricorn) \\
\hline Cancer & Capricorn & Saturn (Aries) & \\
\hline Leo & Aquarius & & \\
\hline Virgo & Pisces & & \\
\hline
\end{tabular}

The normal physiology becomes pathology. The chemo preventive roles of Vitamins and minerals are diluted.

The elemental compositions suggested that vitamins are cosmic hybridization of Sun and Moon. The relationships with minerals and biological precursors have astrological connectivity

Sun - Vitamin A and D, Magnesium and Iodine

Moon - Riboflavin and potassium

Mercury - Thiamine

Jupiter - Vitamin B6 and Choline inositol, Biotin, Manganese, Sulphur, Pangamic acid, Chromium and Zinc

Neptune - Pantothenic acid

Pluto - Orotic acid

The astrological impetus ${ }^{10-16}$ on human pathology was studied with scientific outlook as follows :

Vitamin A - Deficiency is manifested when Sun is determinatl in Libra and Aquarius being enemy of Venus Saturn and Rahu. The skin is the largest organ of human body undergoes loss of complexion, aging and pigmentation. The ophthalmic weakness may be manifested in Libra and Aquarius.

Vitamin B Complex- is essential for nervous system and metabolism. Scorpio and Capricorn need them most. Hydrophilicity of this vitamin is attributed to water sign. Cancer with variability of moods analogous to changes in moon shapes. Moon becomes detrimental in Scorpio, so there is loss of vitamin B- complex through urinogenital system, leading to deficiency.

Vitamin B complex- plays role as coenzymes and they serve as hydrogen carriers in redox reaction that produce the energy for all the cellular processes Niacin, Riboflavin and Pantothenic acid are bio energetically vitals. Scorpio and Capricorn need them most. The former has excretory loss and later need for sluggish metabolism which cause depression. The overall loss of vitality is due to declined bioenergy.
Vitamin C - Water soluble fruits, mountain ash, prevent respiratory system disorder and chemo preventive in Cancer. Mercury is detrimental Pisces but weak in Sagittarius as both signs have common ruler Jupiter.

Vitamin D- It helps in the absorption of calcium and requires sunlight for synthesis. Saturn and Sun are foes of each other, therefore geographical areas deficient in sunlight led to bones disorders and loss of osteocytes in geriatrics.

Vitamin K - Detrimental mars in cancer, negativity support adrenal physiology and reduce tonicity of muscles.

Vitamin E - Debilitated Venus in Virgo may aggravate kidney ovaries and throat disorders due to free radicals attack on bio membranes of these organs.

The triplicity of Zodiacal Signs related with Vitamins demands.

Air signs (Gemini, Libra, Aquarius) - Vitamin A and P

Earth signs (Taurus, Virgo, Capricorn) - Vitamin B, K and $\mathrm{P}$

Fire signs (Aries, Leo, Sagittarius) - Vitamin D

Water signs (Cancer, Scorpio, Pisces) - Vitamin B, C, D, and $\mathrm{K}$

The biochemical and physiological synergy is supported by Vitamin C (hydrophilic), and Vitamin E (lipophilic). Both are potent antioxidants. Their noteworthy functions are Immunomodulation free radical scanvager, longevity and growth promoters, cleaner of GIT junk and dead cells, revitale of body strength, shrinkage of tumor cells, asphoridac for libido/ sex drive. Amazingly they are happy companions of Heart and Kidney.

\section{CONCLUSION}

Vitamins are indispensable for the cellular bioenergetics, metabolic efficiency and chemo preventive for clinical disorders.

An individual (his/her) can ascertain needs of Vitamins according to Zodiacal signs for keeping healthy human physiology therefore Vitamins are medical industry. It is logical to infer that Vitamins have biochemical trust of physiological friendliness.

\section{REFERENCES}

1. The Real Vitamin And Mineral Book By Nancy Burning and Shari Lieberman , 1990

2. The Vitamin Cure By Monte Lai 2018.

3. Let's get well Adelle Davis Abe Books.com

4. Astrology Blogs and Science

5. Tucker Dr W. J. Astriomedical Diagnosis: The Principles of Scientific Medical Astrology' Third Reprint-Pythagore publication, Sidcup kent, 1966.

6. Tucker, Dr W. J. 'Astromedical Resurvey' Pythagorean publication, Sidcup kent, 1965.

7. Bhasin, J.N. "Medical Astrology : a Rational Approach" Sagar Publication, New Delhi 1986.

8. Harvey Ronald 'Mind 'Body in Astrology" Guide-Line for a New Assessment of Astrology in Medicine' L. N. Fowler \& C Ltd, Chadwell Health, Romford, Essex, 1983. 
9. Hoffman, Oscar 'Classical Medical Astrology: Healing with the Elements' The Wessex Astrologer, 2009.

10. Khot, Major S.G. 'Astrology and Diagnosis' Reprinted- Sagar Publications, New Delhi_2005.

11. Davidson, Dr. William M 'Planetary Symptoms of Diseases and Confirming Symptoms - Series of Eight Special Lectures Medical Astrology and Health - Astrological Burea of Consultation, 310, East Nineth Street, New York, N. Y. USA 1959.

12. Hariharan , K. 'Astrological Diagnosis of Diseases Based on K P> System (a Research Study)' Third (Revised) Edition Krishnamurti Publications, Anna Salai, Chennai, 1998
13. Stenudd, Stefan' Your Health in the Horoscope : Introduction to Medical Astrology' Arriba, Malmo, Sweden,2009, Source Here.

14. Starck, Morica, 'Medical Astrology': Healing for the $21^{\text {st }}$ Century' Earth Medicine Books, Santa Fe, New Mexicio 2002.

15. Tucker Dr W. J.Astropharmacology: 'prescribing for the Vital Requirement of Individual form the Evidence offered the Birth Chart Reprinted-pythtagorean publication Sidcup Kent 1969.

16. Jancky Robert Carl 'Introduction of Holistic Medical Astrology' Revised Edition - American Federation of Astrologers, Tampe, Arizona, 1983. 